\title{
Study of intravenous ferric carboxy maltose in iron deficiency anemia in women attending gynecological clinic - safety and efficacy
}

\section{Vineet V. Mishra*, Nisarg Dharaiya, Rohina Aggarwal, Sumesh Choudhary, Khushali Gandhi}

Department of Gynecology, IKDRC-ITS, Civil Hospital, Ahmedabad, India

Received: 26 March 2015

Revised: 16 July 2015

Accepted: 22 July 2015

\section{*Correspondence:}

Dr. Vineet V. Mishra,

E-mail: vineet.mishra.ikdrc@gmail.com

Copyright: (C) the author(s), publisher and licensee Medip Academy. This is an open-access article distributed under the terms of the Creative Commons Attribution Non-Commercial License, which permits unrestricted non-commercial use, distribution, and reproduction in any medium, provided the original work is properly cited.

\begin{abstract}
Background: Several intravenous iron preparations are available for the treatment of iron deficiency anemia (IDA). Some of these require multiple small infusions to prevent labile iron reactions while iron dextran (DEX) is associated with a risk of potentially serious anaphylactic reactions. Ferric carboxymaltose (FCM), a nondextran intravenous iron, is an effective and a safe option which can be administered in high single doses without serious adverse effects.

Methods: It was a prospective study including 150 women of age $>18$ years with a definitive diagnosis of IDA and Hemoglobin $(\mathrm{Hb})$ between 7-10 gm\% from December 2013 to October 2014.Out of these, eleven women were lost to follow up and were excluded from the study. Intravenous FCM (500-1000mg) was administered and the improvement in $\mathrm{Hb}$ levels and iron stores was assessed after 3 weeks of total dose infusion.

Results: Out of 150, 139 women were included in the study. Most of the women were in the age group of 30-39 years $(38.12 \%)$. Most of the patients $(74.10 \%)$ had mild anemia. Mean Hb levels increased over a period of 3 weeks after FCM administration from $8.70 \pm 1.04 \mathrm{gm} \%$ to $11.07 \pm 1.02 \mathrm{gm} \%$ which was statistically significant. Other parameters like S.TIBC (Serum total iron binding capacity), S. Ferritin, S. Iron also suggested a significant improvement after FCM administration. No serious life threatening adverse events were observed with FCM.

Conclusion: Intravenous FCM is an effective and a safe treatment option for IDA and has an advantage of single administration of high doses without serious adverse effects.
\end{abstract}

Keywords: Anaemia in Indian women, Iron therapy, Injectable iron preparations and it's efficacy

\section{INTRODUCTION}

Iron deficiency is recognized as a common nutritional deficiency amongst women of childbearing age in both the developed and developing world and is a leading cause of anemia. Iron deficiency may lead to fatigue, cardiorespiratory problems, increased chances of infection, reduced immunity, depressive episodes and requirement of packed cell transfusion. There are various possible forms of treatment for iron deficiency anemia (IDA). Oral iron is the preferred initial treatment for iron deficiency anemia. However, oral iron supplementation often leads to adverse effects, such as nausea, vomiting, constipation and abdominal pain leading to poor compliance and a poor response to therapy. ${ }^{1}$ In addition, chronic inflammatory conditions may cause poor absorption of iron. Oral iron preparations are also not appropriate for treatment of severe iron deficiency anemia (IDA) where rapid replenishment of iron stores is required. ${ }^{2}$

Various intravenous iron preparations are available for the treatment of IDA. Iron dextran is associated with a potential risk of serious anaphylactic reactions while others need to be given in multiple infusions to avoid labile iron reactions. FCM was approved by US FDA in July 2013 for treatment of IDA. 
FCM can be administered directly over 7-8 min or diluted in saline for infusion The ability to safely inject a single dose as large as $1000 \mathrm{mg}$ in as little as 15 minutes and thereby reduce the need for multiple IV iron infusions render this novel agent a potentially ideal candidate for the treatment of iron deficiency anemia.

The aim of this study was to study the efficacy and safety of FCM in the treatment of IDA.

\section{METHODS}

This was a prospective study conducted over a period from December 2013 to October 2014 including 150 patients attending the Gynecology clinic at the Institute of Kidney Disease and Research Centre (IKDRC).Inclusion criteria were females of more than 18 years of age with a definitive diagnosis of IDA of different etiology and haemoglobin $(\mathrm{Hb})$ between 7 to $10 \mathrm{gm} \%$. Iron deficiency was diagnosed on parameters like complete blood count (CBC), peripheral smear, packed cell volume (PCV), serum ferritin, serum total iron binding capacity (STIBC) and serum iron. History of previous allergic reactions to iron was elicited. Patients were explained about the drug and possible side effects. Informed consent was obtained from all the participants. Patients with anemia of other causes and having hemodynamic instability were excluded. Eleven participants were lost to follow up and were excluded from the study.

Total dose of Ferric Carboxy Maltose (FCM) was calculated on the basis of hemoglobin deficit and body weight using Ganzoni formula:

Total iron deficit $($ milligram $)=$ Body weight $(\mathrm{kg}) \mathrm{x}$ [Target Hb- Actual Hb (gm \%)] x 0.24 +Depot iron (mg)

Depot iron $=15 \mathrm{mg} / \mathrm{kg}$ in case of body weight $<35 \mathrm{Kg}$ and $500 \mathrm{mg}$ in case of weight $>35 \mathrm{~kg}$.

A single dose of FCM should not exceed $1000 \mathrm{mg}$ of iron $(20 \mathrm{ml})$ per day or $15 \mathrm{mg}$ of iron $(0.3 \mathrm{ml})$ per $\mathrm{kg}$ body weight. Not more than $1000 \mathrm{mg}$ of iron $(20 \mathrm{ml})$ was administered in one week. FCM was administered as an infusion diluted in sterile $0.9 \%$ sodium chloride $(\mathrm{NaCl})$ solution. Upto $500 \mathrm{mg}$ FCM can be diluted with $100 \mathrm{ml}$ $\mathrm{NaCl}$ and administered over 6 minutes. Doses between $500 \mathrm{mg}$ to $1000 \mathrm{mg}$ require dilution with $250 \mathrm{ml} \mathrm{NaCl}$ and administration time of 15 minutes. The drug was administered under direct supervision and infusion was immediately stopped in case of any side effects. The patients were followed up after 3 weeks of total dose infusion to assess the status of iron stores and increase in haemoglobin using same parameters as previously mentioned.

\section{RESULTS}

A total of 139 women were included in the study. Age specific distribution of patients is shown in Table 1.
Majority of women were in the age group of 30-39 years (38.12\%). Distribution of all subjects according to WHO classification of degree of anemia is depicted in Table 2. Most of the patients $(74.10 \%)$ had mild anemia while moderate anemia was present in $25.89 \%$ cases. None of the patients had severe anemia. Eighty out of 139 $(57.55 \%)$ women required $1000 \mathrm{mg}$ of FCM, 34\% required $1500 \mathrm{mg}$ of FCM and $25 \%$ required $500 \mathrm{mg}$ of FCM for treatment of IDA as calculated according to Ganzoni formula (Table 3). Those requiring 1500mg FCM were given two infusions at least one week apart. No serious life threatening adverse events were reported. Four subjects had local reactions like itching and irritation at local site and in 5 subjects, systemic reactions in the form of giddiness, headache and nausea were reported (Table 4). Table 5 shows the efficacy of the drug in the treatment of IDA in our study population. There was a significant improvement in haemoglobin levels over a period of 3 weeks from mean $\mathrm{Hb} 8.70 \pm 1.04 \mathrm{gm} \%$ to $11.07 \pm 1.02$ gm\%. Other parameters like S. TIBC, S. Ferritin, S. Iron also suggested a significant improvement after FCM administration. The sense of well being also improved in all patients on follow up.

Table 1: Distribution according to age.

\begin{tabular}{|ll|}
\hline Age in years & No. of patients $(\mathrm{N}-=139)$ \\
\hline $20-29$ & $34(24.46 \%)$ \\
\hline $30-39$ & $53(38.12 \%)$ \\
\hline $40-49$ & $49(35.25 \%)$ \\
\hline $50-70$ & $03(2.15 \%)$ \\
\hline
\end{tabular}

Table 2: Distribution according to degree of anemia (WHO).

\begin{tabular}{|ll|}
\hline Degree of anemia & No of patients $(\mathrm{N}=139)$ \\
\hline Mild $(8$ to $11 \mathrm{gm} / \mathrm{dl})$ & $103(74.10 \%)$ \\
\hline Moderate $(6$ to $7.9 \mathrm{gm} / \mathrm{dl})$ & $36(25.89 \%)$ \\
\hline Severe $(<6 \mathrm{gm} / \mathrm{dl})$ & 00 \\
\hline
\end{tabular}

Table 3: Total dose of FCM required.

\begin{tabular}{|llll|}
\hline $\begin{array}{l}\text { Total Dose } \\
\text { of FCM } \\
\text { required }\end{array}$ & $\begin{array}{l}500 \mathrm{mg}(1 \\
\text { ampoule })\end{array}$ & $\begin{array}{l}1000 \mathrm{mg}(2 \\
\text { ampoule })\end{array}$ & $\begin{array}{l}1500 \mathrm{mg}(3 \\
\text { ampoule })\end{array}$ \\
\hline $\begin{array}{l}\text { No of } \\
\text { patients } \\
(\mathrm{N}=139)\end{array}$ & $\begin{array}{l}25 \\
(17.98 \%)\end{array}$ & $\begin{array}{l}80 \\
(57.55 \%)\end{array}$ & $\begin{array}{l}34 \\
(24.46 \%)\end{array}$ \\
\hline
\end{tabular}

Table 4: Adverse reactions of FCM.

\begin{tabular}{|ll|}
\hline Local reactions & $4 / 139(2.87 \%)$ \\
\hline Systemic reactions & $5 / 139(3.59 \%)$ \\
\hline Total adverse reactions & $9 / 139(6.47 \%)$ \\
\hline
\end{tabular}


Table 5: Laboratory parameters before and after FCM administration.

\begin{tabular}{|c|c|c|c|c|}
\hline $\begin{array}{l}\text { Seria } \\
\text { I No. }\end{array}$ & Variables & Pre values & Post values & $\begin{array}{l}p- \\
\text { value }\end{array}$ \\
\hline 1 & $\begin{array}{l}\text { Hemoglobi } \\
\mathrm{n}(\mathrm{gm} / \mathrm{dl})\end{array}$ & $8.70 \pm 1.04$ & $11.07 \pm 1.02$ & $\begin{array}{l}<0.00 \\
*\end{array}$ \\
\hline 2 & PCV (\%) & $31.44 \pm 29.82$ & $36.23 \pm 2.38$ & $\begin{array}{l}0.06 \\
\text { (NS) }\end{array}$ \\
\hline 3 & $\begin{array}{l}\text { S.TIBC } \\
(\mu \mathrm{gm} / \mathrm{dl})\end{array}$ & $\begin{array}{l}353.84 \pm 107.1 \\
2\end{array}$ & $\begin{array}{l}275.15 \pm 208.9 \\
3\end{array}$ & $\begin{array}{l}<0.00 \\
*\end{array}$ \\
\hline 4 & $\begin{array}{l}\text { S.Ferritin } \\
(\mathrm{ng} / \mathrm{dl})\end{array}$ & $23.76 \pm 58.88$ & $99.77 \pm 31.53$ & $\begin{array}{l}<0.00 \\
*\end{array}$ \\
\hline 5 & $\begin{array}{l}\text { S.Iron } \\
(\mu \mathrm{gm} / \mathrm{dl})\end{array}$ & $39.43 \pm 20.17$ & $85.81 \pm 26.04$ & $\begin{array}{l}<0.00 \\
*\end{array}$ \\
\hline 6 & $\begin{array}{l}\text { Reticulocyt } \\
\text { e count }(\%)\end{array}$ & $0.96 \pm 0.53$ & $0.96 \pm 0.17$ & $\begin{array}{l}0.91 \\
\text { (NS) }\end{array}$ \\
\hline
\end{tabular}

\section{DISCUSSION}

FCM is a novel ferric hydroxide carbohydrate complex which when administered intravenously is effective in the treatment of IDA due to various reasons such as abnormal uterine bleeding, inflammatory bowel disease, post partum IDA or chronic renal disease. It provides controlled delivery of iron to target tissues with a minimal risk of release of large amount of ionic iron in the serum thus preventing adverse events seen with other iron preparations. ${ }^{3}$ One of the earliest intravenous iron preparation containing dextran was associated with the risk of serious allergic or anaphylactic reactions. ${ }^{4}$ Subsequent iron preparations such as iron sucrose or ferric gluconate resulted in fewer hypersensitivity reactions but the iron carbohydrate complex was less stable with a risk of toxic reactions to non transferrinbound iron. So, large doses could not be administered at a time and multiple infusions were required. ${ }^{4}$ FCM has a more stable structure as compared to iron sucrose and ferric gluconate. Therefore large doses can be administered over shorter periods resulting in rapid replenishment of iron stores with fewer administrations. ${ }^{3,5,6}$ The risk of hypersensitivity reactions seen with dextran is reduced with FCM. FCM has been shown to be an effective option in the treatment of IDA in multiple studies and it also improves the quality of life. $^{3,5,6}$ Several randomized trials have shown effectiveness of FCM in treatment of IDA with rapid replenishment of iron stores. FCM was well tolerated in these trials and had better compliance than other iron preparations. $^{7-9}$ The results of our study were consistent with previous trials. There was an increase in mean hemoglobin levels with replenishment of iron stores and clinical improvement after FCM administration. FCM was well tolerated and was associated with few local reactions and mild systemic reactions but no serious life threatening allergic reactions were reported. Thus FCM is a safe and an effective treatment option for IDA. ${ }^{13}$

Most of the studies have shown that FCM is relatively safe with a low incidence of adverse effects. Most common adverse effects noted were nausea, diarrhea, bloating, abdominal pain, headache and rash. ${ }^{13}$ Serious adverse reactions noted were unrelated to FCM administration. ${ }^{14}$ These findings were similar to our study.

\section{CONCLUSION}

FCM is a safe and an effective treatment option for IDA of various etiologies in patients who are noncompliant or unresponsive to oral iron or where oral iron is not suitable for treatment as in cases of severe anemia where rapid replenishment of iron stores is required.

Funding: No funding sources

Conflict of interest: None declared

Ethical approval: The study was approved by the Institutional Ethics Committee

\section{REFERENCES}

1. Killip S, Bennett J, Chambers M. Iron deficiency anemia. Am Fam Physician. 2007;75:671-8.

2. Silverstein SB, Gilreath JA, Rodgers GM. Intravenous iron therapy: a summary of treatment options and review of guidelines. Journal of Pharmacy Practice, 2008; 21(6):431-43.

3. Lyseng-Williamson KA, Keating GM. Ferric carboxymaltose: a review of its use in irondeficiency anaemia. Drugs. 2009;69(6):739-56.

4. Qunibi W. The efficacy and safety of current intravenous iron preparations for the management of iron-deficiency anaemia: a review. Arzneimittelforschung. 2010;60:399-412.

5. Van Wyck DB, Martens MG, Seid MH, Baker JB, Mangione A. Intravenous ferric carboxymaltose compared with oral iron in the treatment of postpartum anemia: a randomized controlled trial. Obstetrics and Gynecology. 2007;110(2):267-78.

6. Goodnough LT, Van Wyck DB, Mangione A, Morrison J, Hadley PE, Jehle JA. Large-dose intravenous ferric carboxymaltose injection for iron deficiency anemia in heavy uterine bleeding: a randomized, controlled trial. Transfusion. 2009;49(12):2719-28.

7. Bregman DB, Goonough LT. Experience with intravenous ferric carboxymaltose in patients with iron deficiency anemia Ther Adv Hematol. 2014;5(2):48-60.

8. Evstatiev R, Marteau P, Iqbal T, Khalif IL, Stein J, Bokemeyer B, et al. FERGI Study Group FERGIcor, a randomized controlled trial on ferric carboxymaltose for iron deficiency anemia in inflammatory bowel disease. Gastroenterology. 2011;141(3):846-53.

9. Hussain I, Bhoyroo J, Butcher A, Todd A. Koch, Andy He and David B. Bregman. Direct Comparison of the Safety and Efficacy of Ferric Carboxymaltose versus Iron Dextran in Patients with Iron Deficiency Anemia. Anemia. Volume 2013 (2013), Article ID 169107, 10 pages. 
10. Barish CF, Koch T, Butcher A, Morris D, Bregman DB. Safety and efficacy of intravenous ferric carboxymaltose $(750 \mathrm{mg})$ in the treatment of iron deficiency Anemia: two randomized, controlled trials. Anemia 2012;2012:1-12.

11. Charytan C, Bernardo MV, Koch T, Butcher A, Morris D, Bregman DB. Intravenous ferric carboxymaltose versus standard medical care in the treatment of iron deficiency anemia in patients with chronic kidney disease: a randomized, activecontrolled, multi-center study. Nephrology Dialysis Transplantation. 2013;28:953-64.

12. Wolf M, Koch TA, Bregman DB. Effects of iron deficiency anemia and its treatment on fibroblast growth factor 23 and phosphate homeostasis in women. Journal of Bone and Mineral Research. 2013;28(8):1793-803.
13. Anker SD, Colet JC, Filippatos G, et al. Ferric carboxymaltose in patients with heart failure and iron deficiency. The New England Journal of Medicine. 2009;361(25):2436-48.

14. Kulnigg S, Stoinov S, Simanenkov V, et al. A novel intravenous iron formulation for treatment of anemia in inflammatory bowel disease: the ferric carboxymaltose (FERINJECT) randomized controlled trial. American Journal of Gastroenterology. 2008;103(5):1182-92.

Cite this article as: Mishra VV, Dharaiya N, Aggarwal R, Choudhary S, Gandhi K. Study of intravenous ferric carboxy maltose in iron deficiency anemia in women attending gynecological clinic safety and efficacy. Int J Reprod Contracept Obstet Gynecol 2015;4:968-71. 